\title{
Application of remote sensing and geographical information system for generation of runoff curve number
}

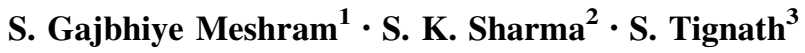

Received: 22 March 2015 / Accepted: 5 October 2015/Published online: 17 October 2015

(C) The Author(s) 2015. This article is published with open access at Springerlink.com

\begin{abstract}
Watershed is an ideal unit for planning and management of land and water resources (Gajbhiye et al., IEEE international conference on advances in technology and engineering (ICATE), Bombay, vol 1, issue 9, pp 23-25, 2013a; Gajbhiye et al., Appl Water Sci 4(1):51-61, 2014a; Gajbhiye et al., J Geol Soc India (SCIIF 0.596) 84(2):192-196, 2014b). This study aims to generate the curve number, using remote sensing and geographical information system (GIS) and the effect of slope on curve number values. The study was carried out in Kanhaiya Nala watershed located in Satna district of Madhya Pradesh. Soil map, Land Use/Land cover and slope map were generated in GIS Environment. The CN parameter values corresponding to various soil, land cover, and land management conditions were selected from Natural Resource Conservation Service (NRCS) standard table. Curve number $(\mathrm{CN})$ is an index developed by the NRCS, to represent the potential for storm water runoff within a drainage area. The $\mathrm{CN}$ for a drainage basin is estimated using a combination of land use, soil, and antecedent soil moisture condition (AMC). In present study effect of slope on $\mathrm{CN}$ values were determined. The result showed that the $\mathrm{CN}$ unadjusted value are higher in comparison to $\mathrm{CN}$ adjusted with slope. Remote sensing and
\end{abstract}

S. Gajbhiye Meshram

gajbhiyesarita@gmail.com

1 Department of Water Resources Development and Management, IIT, Roorkee, Uttarakhand, India

2 Department of Soil and Water Engineering, College of Agricultural Engineering, J.N.K.V.V., Jabalpur, MP, India

3 Department of Geology, Government Autonomous Model Science College, Jabalpur, MP, India
GIS is very reliable technique for the preparation of most of the input data required by the SCS curve number model.

Keywords SCS-CN $\cdot$ Runoff - Watershed - Remote sensing $\cdot$ Geographical information system

\section{Introduction}

Water resources development plays an important role in achieving multifaceted economic and social development of a nation. India is endowed with substantial water resources in accordance with latest estimates of Central Water Commission, annual runoff of its river systems aggregates to $1800 \mathrm{~km}^{3}$ constituting $4 \%$ of total annual water flows of the world. As the population of India is about $16 \%$ of world's population, there is greater pressure on use of water to meet the demand in this country. A substantial progress has been made in development and management of water resources in the last 50 years. However, the pace of development in the water resources has lead to the exploitation of the water resources in leaps and bounds, resulting in overuse of surface supplies and over exploitation of ground water. Therefore, at this stage one has to realize the need and importance of conservation of water. At the outset water resources planning is a prerequisite for any developmental activities.

As regards planning, watershed development program has become widely accepted concept, which is based on overall exploitation of total resources. Water resources project in general lacks planning in most of the cases due to pressure from various sectors without taking into consideration of developmental possibilities. Therefore, before taking up any water resources development project, the prime necessity is to know the probable quantity of water 
available from a watershed. For the estimation of amount of direct runoff that will be produced from a given precipitation from a basin, various hydrologic models are available. Amongst these models, Soil Conservation Services (SCS) model now called as NRCS is most widely used for the direct runoff in the ungauged basins. This model combines watershed parameters and climatic factors in one entity called the Curve Number.

The method was developed in 1954 by the USDA Soil Conservation Service (Rallison 1980), and is described in the Soil Conservation Services (SCS) National Engineering handbook Sect. 4: Hydrology (NEH-4) (SCS 1985). The first version of the handbook was published in 1954. Subsequent revision followed in 1956, 1964, 1965, 1971, 1972, 1985 and 1993. The SCS-CN method has become the focus of much discussion in recent hydrological literature. For example, Ponce and Hawkins (1996) critically examined this method; clarified its conceptual and empirical basis; delineated its capabilities, limitations, and uses; and identified areas of research. Yu (1998) derived the SCS-CN method analytically assuming exponential distribution for the spatial variation of the infiltration capacity and the temporal variation of the rainfall rate. Hjelmfelt (1991), Hawkins (1993) and Bonta (1997) suggested procedures for determining curve numbers using field data of storm rainfall and runoff. Moglen (2000) discussed the effect of spatial variability of $\mathrm{CN}$ on the computed runoff. Mishra et al. (2013)modified the SCS-CN method by accounting for the static portion of infiltration and the antecedent moisture. Mishra and Singh (2004) studied the validity and extension of the SCS-CN method for computing infiltration and rainfall-excess rates. Mishra et al. (2006) improved the relation between the initial abstraction $\left(I_{\mathrm{a}}\right)$ and the potential maximum storage $(S)$ incorporating antecedent moisture in SCS-CN methodology. Many models, such as AGNPS (Young et al. 1989), TR-55, TR-20, HIC-1, WMS, and HICHMS adopt SCS-CN method for runoff calculation. Gajbhiye et al. 2014a, b, c, d find relationship between SCS-CN and sediment yield, Gajbhiye et al. 2015a, b simplified sediment yield index model incorporating parameter $\mathrm{CN}$. The SCS-CN method does not take into account the effect of slope on runoff yield because cultivated land in general has slope of less than $5 \%$ and the slope $<5 \%$ does not influence the $\mathrm{CN}$ value significantly. However, there are few models which incorporate a slope factor to $\mathrm{CN}$ method to improve estimation of surface runoff depth and volume (Huang et al. 2006). Those which had taken the slope factor into account are Sharpley and Williams (1990) and Huang et al. (2006). Thus, only a few attempts have been made to include the slope factor into the $\mathrm{CN}$ method.

Conventional methods of runoff estimation using SCS model are time consuming and error prone. Thus, Remote Sensing and geographical information system (GIS) techniques are being increasingly used, as all the factors of SCS model are geographic in character. Some of the researcher in India attempted the application of remote sensing (RS) and GIS (Gajbhiye and Sharma 2012, 2015a, b; Gajbhiye et al. 2014a, b, c, d, 2015a, b; Gajbhiye 2015a). Due to geographic nature of these factors of SCS runoff model can easily be modelled into GIS. Some of the research worker in India has attempted to calculate runoff curve number using satellite data. Gajbhiye and Mishra 2012, estimate runoff using SCS-CN method through RS and GIS application in Kanhaiya watershed, Gajbhiye $2015 \mathrm{~b}$ estimated surface runoff using RS and GIS. Gajbhiye et al. 2013b find a monthly and seasonal variation of runoff curve number of the Narmada watershed. Gajbhiye et al. 2013a, Mishra et al. 2013 design runoff curve number for Narmada Watershed (India). Gajbhiye (2014) estimation of Rainfall generated runoff using RS and GIS. Looking to all these facts a study was undertaken with the objective to generate Curve number using RS and GIS and to see the effect of slope on $\mathrm{CN}$ value.

\section{Materials and methods}

\section{Study area}

The study area Kanhaiya nala watershed which lies within the Tons River catchment is situated between $80^{\circ} 31^{\prime}$ $51.01^{\prime \prime}$ to $80^{\circ} 35^{\prime} 17.05 \mathrm{E}$ longitude and $24^{\circ} 06^{\prime} 29.23^{\prime \prime}$ to $24^{\circ} 11^{\prime} 05.03^{\prime \prime}$ latitude with elevation range 480-620 m above Mean Sea Level (MSL) and extends a total area of 2352.65 ha. Kanhaiya nala Watershed situated in Satna District (MP) is shown in Fig. 1. The total area of the watershed is $19.53 \mathrm{~km}^{2}$. It has a typical subtropical climate with hot dry summers and cool dry winters. Temperature extremes vary between the minimum of $4{ }^{\circ} \mathrm{C}$ during December or January months to the maximum of $45{ }^{\circ} \mathrm{C}$ in May or June. Average annual precipitation is $1100 \mathrm{~mm}$, which is concentrated mostly between Mid-June and MidSeptember with scattered winter rains during late December and January months.

\section{Data source}

Topographic map at the scale of 1:50,000 prepared by Survey of India (SOI) was used for delineation of the watershed. SOI toposheet no. $63 \mathrm{D} / 12$ was used for the delineation of watershed boundary. The Landsat ETM satellite data, with $30 \mathrm{~m}$ resolution procured from Global Land Cover Facility (GLCF), Maryland, with the date of pass 11 Oct 2006 were used to prepare the LULC map of watershed. Soil map prepared by National Bureau of Soil 


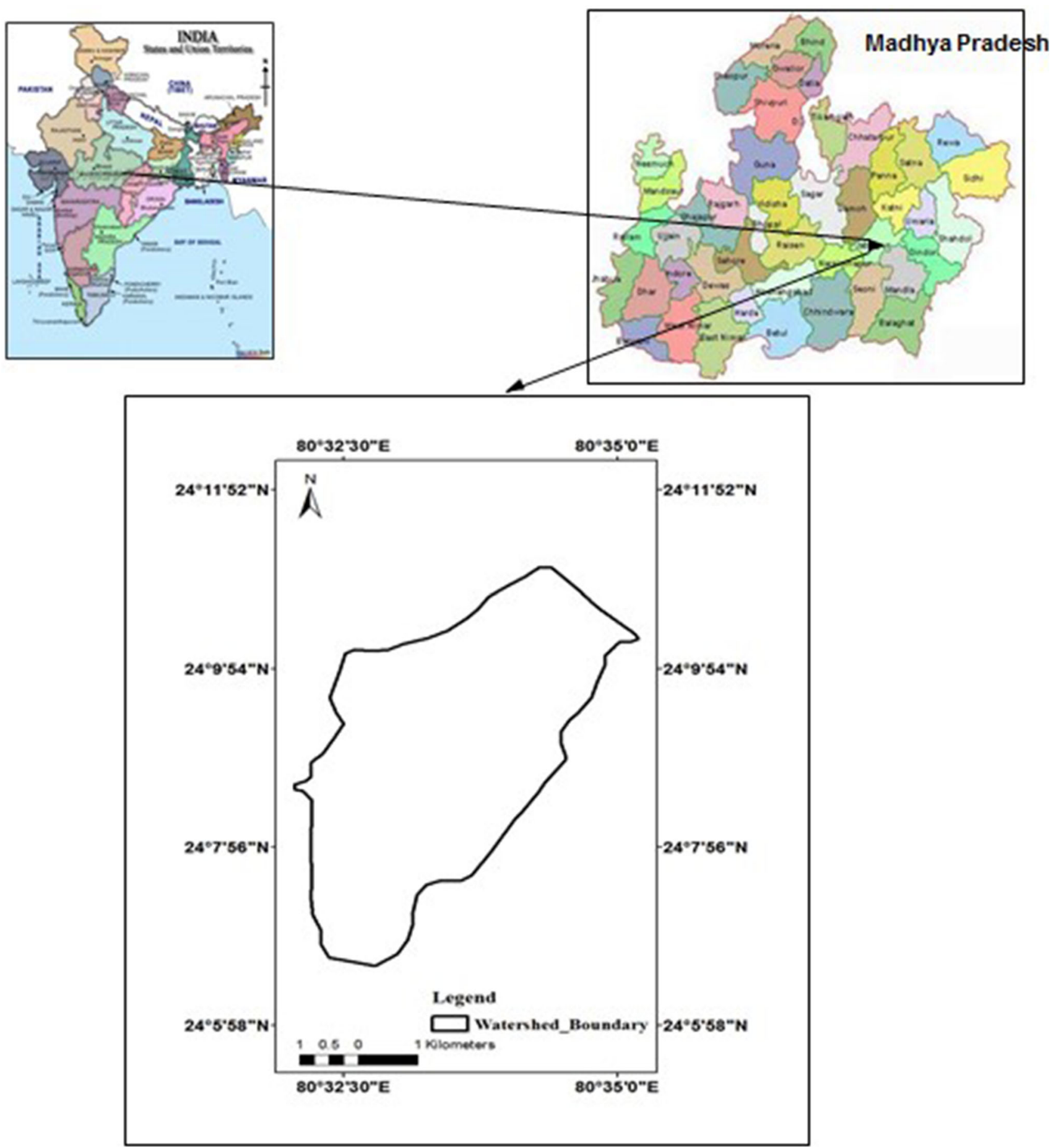

Fig. 1 Location map of the study area

Survey on 1:250,000 and printed on 1:500,000 was used to prepare soil map of study area.

\section{Software used}

Arc view 3.1 power GIS software was used for creating, managing and generation of different layer and maps.
ERDAS 9.1 was used for generation of LULC map. The Microsoft excel was used for mathematical calculation.

\section{LULC map}

The LULC map was generated with the help of satellite data using unsupervised classification. In Kanhaiya Nala 


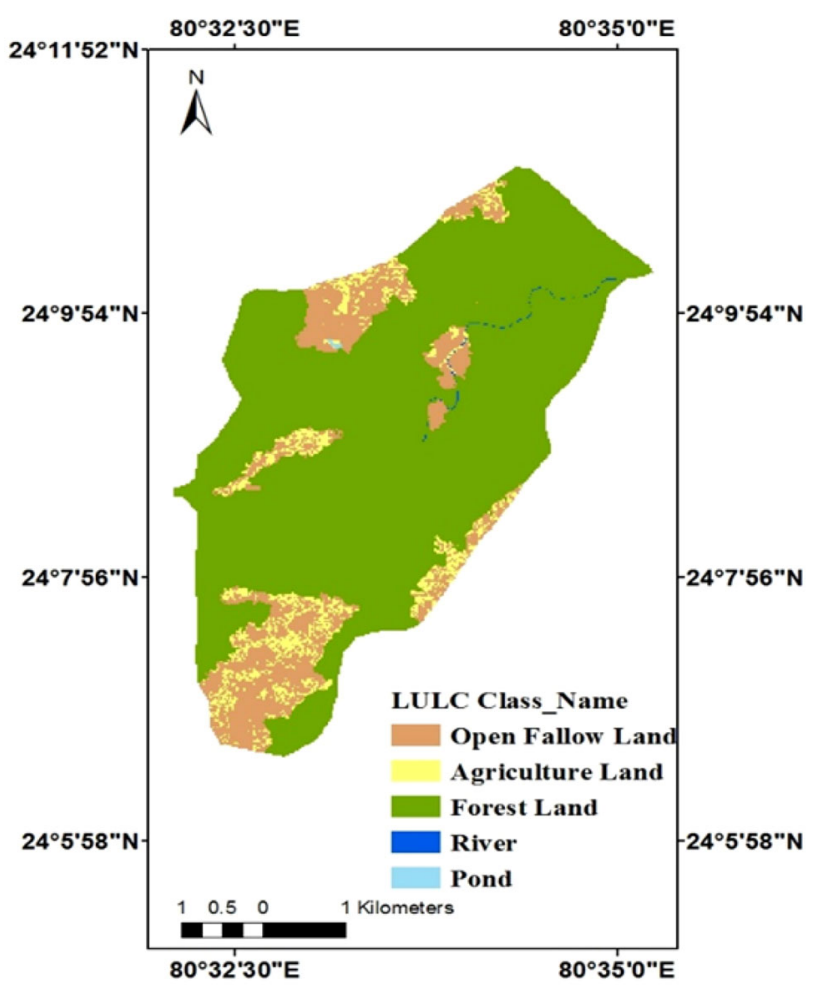

Fig. 2 LULC map of the watershed

watershed five land use/land cover classes were identified, i.e., river, pond, open land, agriculture and forest (Fig. 2; Table 2).

\section{Soil map}

Soil map of Madhya Pradesh has been prepared by NBSS and LUP and it published on 1:500,000 scale in nine sheets. Sheet no. 4 has the soil map of study area. So, the same has been scanned and further GIS operation has been made in Arc Info. In present study only one type of soil (loamy) was present (Fig. 3) which comes under the hydrologic soil group B.

\section{Slope map}

The slope has major influence on the soil and water of the watershed and thereby influences the land use capability. The percentage slope determines the erosion susceptibility of the soil depending on its nature. The slope map (Fig. 4) was generated from the contour of survey of India toposheet at 1:50,000 scale following $20 \mathrm{~m}$ contour interval. The contour was digitized using ARC GIS 9.3.

\section{Preparation of CN map}

To prepare CN map, the soil map and land use map were uploaded to the arc view. The soil map and land use map

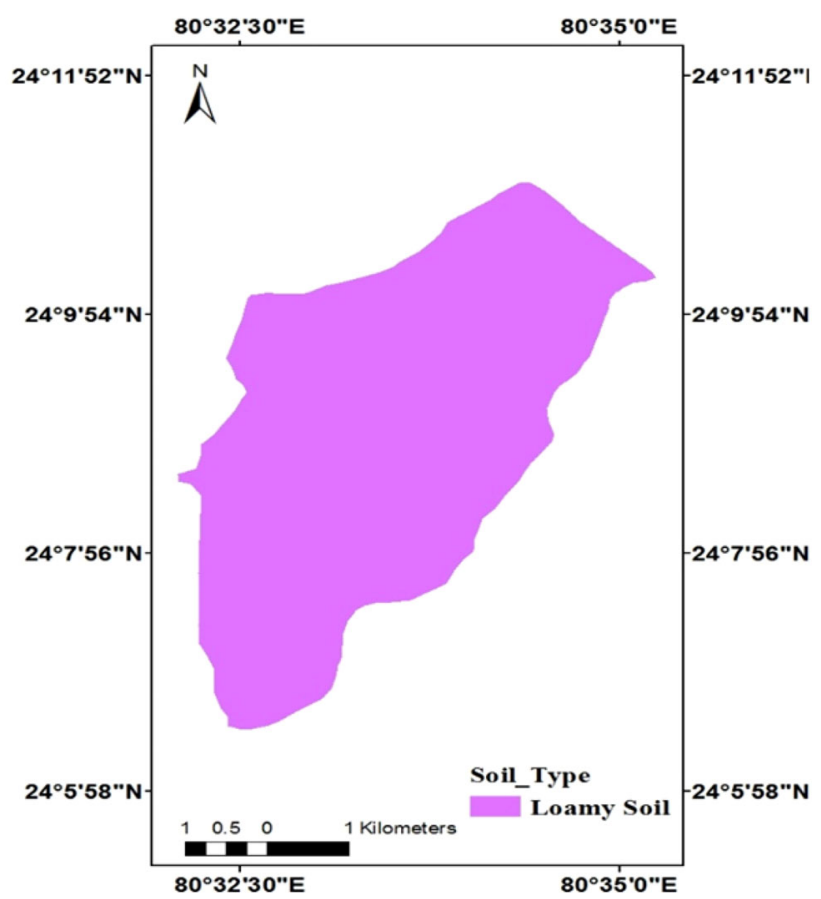

Fig. 3 Soil map of the watershed

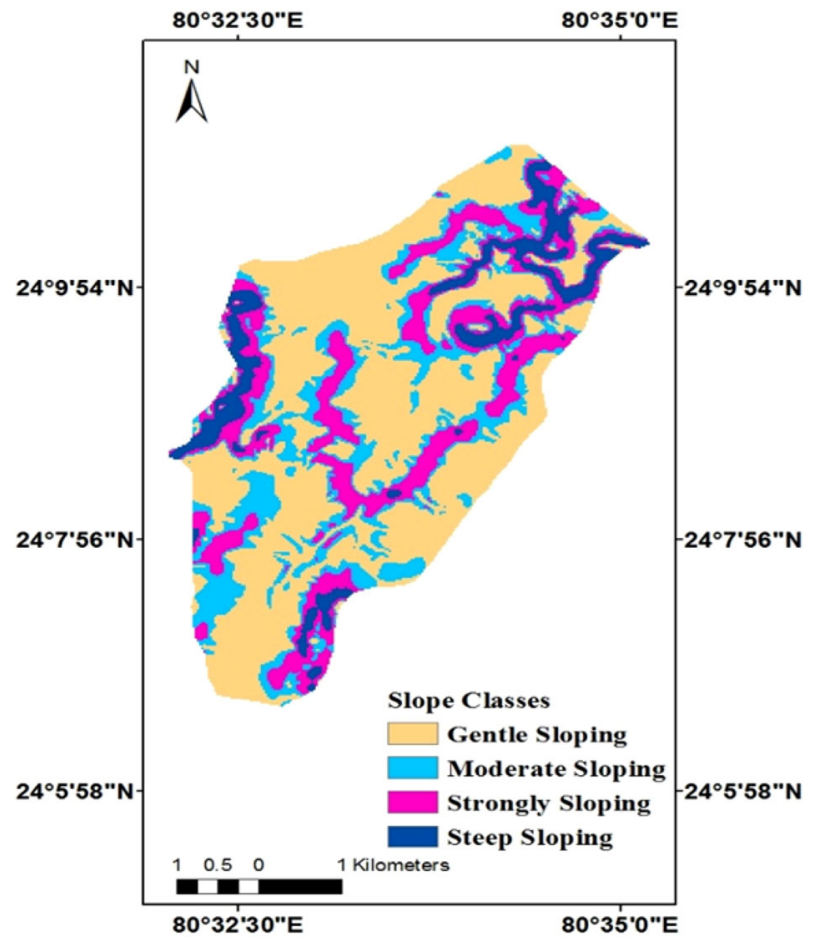

Fig. 4 Slope (\%) map of the watershed

were selected for intersection, after intersection a map with new polygon representing the merged soil-land map. The appropriate $\mathrm{CN}$ value for each polygon of the soil-land map was assigned (see Fig. 5; Table 1). 


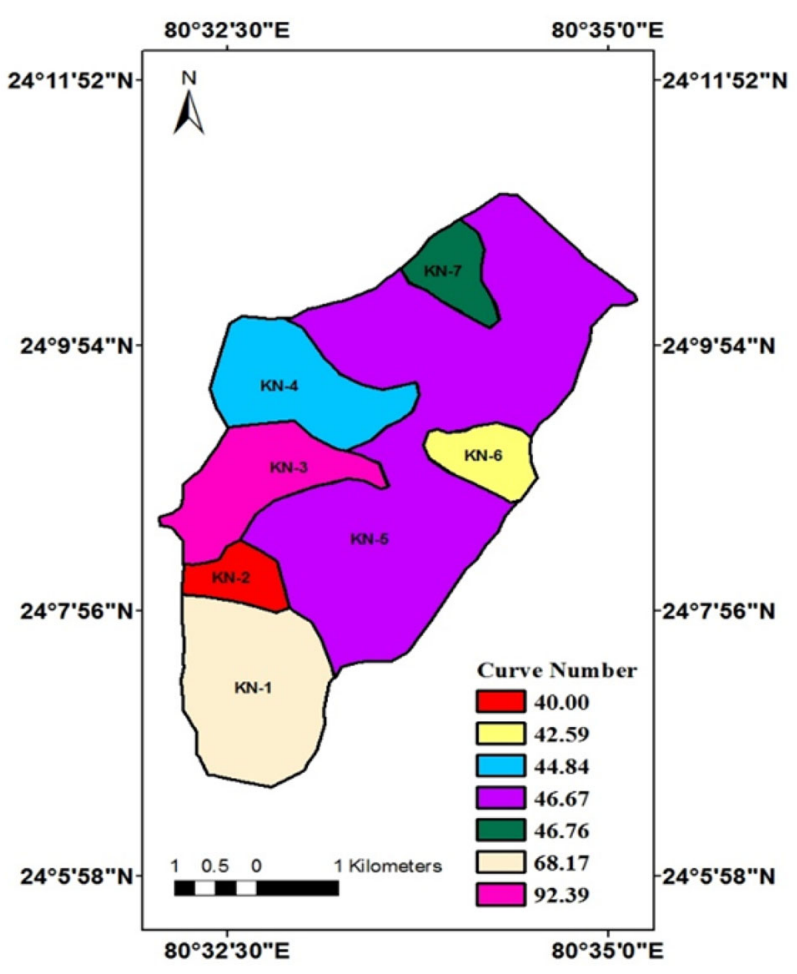

Fig. $5 \mathrm{CN}$ map of the watershed
$\mathrm{CN}=\left(\sum\left(\mathrm{CN}_{i} \times A_{i}\right)\right) / A$

where $\mathrm{CN}=$ weighted curve number. $\mathrm{CN}_{i}=$ curve number from 1 to any no. N. $A_{i}=$ area with curve number $\mathrm{CN}_{i} A=$ the total area of the watershed.

\section{Calculating slope adjusted $\mathrm{CN}$}

The NRCS-CN method does not take into account the effect of slope on runoff

$\mathrm{CN} 2 \alpha=\mathrm{CN} 2 \times K$

$K=\frac{322.79+15.63 \alpha}{\alpha+323.52}$

where $K=\mathrm{CN}$ constant and $\mathrm{CN} 2 \alpha=$ value of $\mathrm{CN} 2$ for a given slope.

Slope and CN map were intersected to get slope of each polygon, since each polygon has different slope, then calculation of weighted slope is need for each polygon. Weighted slope of polygon was computed using formula

Weighted slope $=\frac{\sum(\mathrm{Ai} \times \mathrm{Si})}{A}$

where $\mathrm{Ai}=$ area of slope (ha), $\mathrm{Si}=$ slope $(\%)$ and $A=$ polygon area (ha).

Table 1 Runoff curve numbers for (AMC II) for the Indian conditions

\begin{tabular}{|c|c|c|c|c|c|c|c|}
\hline \multirow[t]{2}{*}{ SI no. } & \multirow[t]{2}{*}{ Landuse } & \multirow[t]{2}{*}{ Treatment/practice } & \multirow[t]{2}{*}{ Hydrologic condition } & \multicolumn{4}{|c|}{ Hydrologic soil group } \\
\hline & & & & A & B & $\mathrm{C}$ & $\mathrm{D}$ \\
\hline \multirow[t]{8}{*}{1} & \multirow[t]{8}{*}{ Cultivated } & Straight row & - & 76 & 86 & 90 & 93 \\
\hline & & \multirow[t]{2}{*}{ Contoured } & Poor & 70 & 79 & 84 & 88 \\
\hline & & & Good & 65 & 75 & 82 & 86 \\
\hline & & \multirow[t]{2}{*}{ Contoured and terraced } & Poor & 66 & 74 & 80 & 82 \\
\hline & & & Good & 62 & 71 & 77 & 81 \\
\hline & & \multirow[t]{2}{*}{ Bunded } & Poor & 67 & 75 & 81 & 83 \\
\hline & & & Good & 59 & 69 & 76 & 79 \\
\hline & & Paddy (rice) & - & 95 & 95 & 95 & 95 \\
\hline \multirow[t]{2}{*}{2} & \multirow[t]{2}{*}{ Orchards } & With under stony cover & - & 39 & 53 & 67 & 71 \\
\hline & & Without under stony cover & & 41 & 55 & 69 & 73 \\
\hline \multirow[t]{3}{*}{3} & \multirow[t]{3}{*}{ Forest } & Dense & - & 26 & 40 & 58 & 61 \\
\hline & & Open & & 28 & 44 & 60 & 64 \\
\hline & & Shrubs & & 33 & 47 & 64 & 61 \\
\hline \multirow[t]{3}{*}{4} & \multirow[t]{3}{*}{ Pasture } & \multirow[t]{3}{*}{-} & Poor & 68 & 79 & 86 & 89 \\
\hline & & & Fair & 49 & 69 & 79 & 84 \\
\hline & & & Good & 39 & 61 & 74 & 80 \\
\hline 5 & Wasted land & - & - & 71 & 80 & 85 & 88 \\
\hline 6 & Hard surface & - & - & 77 & 86 & 91 & 93 \\
\hline
\end{tabular}


Table 2 Land use/land cover classification of the Kanhaiya Nala watershed

\begin{tabular}{llcc}
\hline S. no. & Classes & Area $\left(\mathrm{km}^{2}\right)$ & Percentage \\
\hline 1 & Open land & 2.79 & 14.28 \\
2 & Agriculture & 1.11 & 5.68 \\
3 & Forest & 15.56 & 79.67 \\
4 & River & 0.04 & 0.20 \\
5 & Pond & 0.03 & 0.15 \\
Total & & 19.53 & 100 \\
\hline
\end{tabular}

Table 3 Curve number for Kanhaiya Nala watershed

\begin{tabular}{lllll}
\hline S. no & $\begin{array}{l}\text { Sub- } \\
\text { watershed }\end{array}$ & $\begin{array}{l}\text { CN } \\
\text { (AMCII) }\end{array}$ & $\begin{array}{l}\text { Slope adjusted } \\
\text { CN (AMCII) }\end{array}$ & $\begin{array}{l}\text { Weighted } \\
\text { slope }(\%)\end{array}$ \\
\hline 1 & $\mathrm{KN}_{1}$ & 68.17 & 68.10 & 3.96 \\
2 & $\mathrm{KN}_{2}$ & 40.00 & 39.96 & 4.39 \\
3 & $\mathrm{KN}_{3}$ & 92.39 & 92.29 & 4.33 \\
4 & $\mathrm{KN}_{4}$ & 44.84 & 44.79 & 3.09 \\
5 & $\mathrm{KN}_{5}$ & 46.76 & 46.66 & 2.23 \\
6 & $\mathrm{KN}_{6}$ & 42.59 & 42.50 & 1.96 \\
7 & $\mathrm{KN}_{7}$ & 46.76 & 46.71 & 3.56 \\
\hline
\end{tabular}

\section{Result and discussion}

The soil of the Kanhaiya Nala watershed is loamy, which comes under the hydrologic soil group 'B' (Fig. 3). The study watershed was delineated into seven subwatersheds. The land use/land cover classification of the watershed is presented in Table 2. On the basis of unsupervised classification the classes namely River $(0.20 \%)$, Pond $(0.03 \%)$, Open/fallow land (14.28\%), Agriculture land (5.68\%) and Forest $(79.67 \%)$ were identified. Further land use/land cover digital data was used for generation of $\mathrm{CN}$.

\section{Curve number}

The USDA curve number table modified for Indian conditions was used for the determination of the curve number for individual sub watersheds based on the hydrological soil groups and land use classes of respective areas. The weighted $\mathrm{CN}$ (AMCII) and slope adjusted $\mathrm{CN}$ (AMCII) values are given in Table 3.

The weighted $\mathrm{CN}$ value of sub watershed $1,2,3,4,5,6$, and 7 comes to be $68.17,40.00,92.39,44.84,46.76,42.59$ and 46.76, respectively. And slope adjusted $\mathrm{CN}$ value for sub watershed $1,2,3,4,5,6$, and 7 to be $68.10,39.96$, $92.29,44.79,46.66,42.50$ and 46.71 , respectively. It can be inferred from Table 3 that the $\mathrm{CN}$ unadjusted value are higher in comparison to $\mathrm{CN}$ adjusted with slope.

There is no provision for runoff monitoring in Kanhaiya Nala watershed, therefore this method could be used to find out the runoff. Thus, the generated curve numbers may be used for prediction of runoff from an ungauged watershed.

\section{Conclusion}

The synoptic concept of satellite image in remote sensing and GIS application is fairly easy for identification of the broad physical features such as stream network, land use/land cover, soils surface, water bodies, etc. which are necessary input parameters for estimation of runoff using NRCS model. In the present study the $\mathrm{CN}$ unadjusted value are higher in comparison to $\mathrm{CN}$ adjusted with slope. Although curve number method is empirical approach to determine the runoff depth from watersheds, it can be useful for estimating the runoff for places which do not have runoff record. Moreover, study on the curve number behavior of watersheds can be carried out to distinguish watershed behavior for soil and water conservation planning.

Open Access This article is distributed under the terms of the Creative Commons Attribution 4.0 International License (http:// creativecommons.org/licenses/by/4.0/), which permits unrestricted use, distribution, and reproduction in any medium, provided you give appropriate credit to the original author(s) and the source, provide a link to the Creative Commons license, and indicate if changes were made.

\section{References}

Bonta JV (1997) Determination of watershed curve number using derived distributions. J Irrig Drain Eng ASCE 123(1):28-36

Gajbhiye S (2014) Estimation of rainfall generated runoff using RS and GIS. LAMBERT Academic Publishing, Germany. ISBN 978-3-659-61084-4

Gajbhiye S (2015a) Morphometric analysis of a Shakkar river catchment using RS and GIS. Int J U- E-Serv Sci Technol 8(2):11-24 (ISSN: 2005-4246)

Gajbhiye S (2015b) Estimation of surface runoff using remote sensing and geographical information system. Int $\mathrm{J}$ U- E-Serv Sci Technol 8(4):118-122 (ISSN: 2005-4246)

Gajbhiye S, Mishra SK (2012) Application of NRSC-SCS curve number model in runoff estimation using RS \& GIS. In: IEEEinternational conference on advances in engineering science and management (ICAESM -2012) Nagapattinam, Tamil Nadu, March 30-31, pp 346-352 (ISBN: 978-81-909042-2-3)

Gajbhiye S, Sharma SK (2012) Land use and land cover change detection through remote sensing using multi-temporal satellite data. Int J Geomat Geosci 3(1):89-96 (ISSN 0976-4380)

Gajbhiye S, Sharma SK (2015a) Applicability of remote sensing and gis approach for prioritization of watershed through sediment yield index. Int J Sci Innov Eng Technol 1:1-6

Gajbhiye S, Sharma SK (2015b) Prioritization of watershed through morphometric parameters: a PCA based approach. Appl Water Sci. doi:10.1007/s13201-015-0332-9 
Gajbhiye S, Mishra SK, Pandey A (2013a) A procedure for determination of design runoff curve number for Bamhani Watershed. In: IEEE-international conference on advances in technology and engineering (ICATE), Bombay, vol 1, issue 9, pp 23-25

Gajbhiye S, Mishra SK, Pandey A (2013b) Effect of seasonal/monthly variation on runoff curve number for selected watersheds of Narmada Basin. Int J Environ Sci 3(6):2019-2030 (ISSN 0976-4402)

Gajbhiye S, Mishra SK, Pandey A (2014a) Prioritizing erosion-prone area through morphometric analysis: an RS and GIS perspective. Appl Water Sci 4(1):51-61 (ISSN 2190-5495)

Gajbhiye S, Mishra SK, Pandey A (2014b) Hypsometric analysis of Shakkar river catchment through geographical information system. J Geol Soc India (SCI-IF 0.596) 84(2):192-196 (ISSN 0974-6889)

Gajbhiye S, Mishra SK, Pandey A (2014c) Relationship between SCS-CN and sediment yield. Appl Water Sci 4(4):363-370 (ISSN: 2190-5495)

Gajbhiye S, Sharma SK, Meshram C (2014d) Prioritization of watershed through sediment yield index using RS and GIS approach. Int J U- E-Serv Sci Technol 7 (6):47-60 (ISSN: 2005-4246)

Gajbhiye S, Mishra SK, Pandey A (2015a) Simplified sediment yield index model incorporating parameter CN. Arabian J Geosci (SCI-IF 1.224) 8(4):1993-2004 (ISSN: 1866-7511)

Gajbhiye S, Sharma SK, Tignath S, Mishra SK (2015b) Development of a geomorphological erosion index for Shakkar watershed. Geol Soc India 86 (3):361-370 (SCI-IF 0.596) (ISSN: 0016-7622)

Hawkins RH (1993) Asymptotic determination of runoff curve numbers from data. J Irrig Drain Eng ASCE 119(2):334-345

Hjelmfelt AT (1991) Investigation of curve number procedure. J Hydraul Eng 117(6):725-737
Huang GH, Zhang RD, Haung QZ (2006) Modelling soil water retention curve with fractal method. Pedosphere 16(2):137-146

Mishra SK, Singh VP (2004) Long-term hydrologic simulation based on the soil conservation service curve number. Hydrol Process 18(7):1291-1313

Mishra SK, Tyagi JV, Singh VP, Singh R (2006) SCS-CN based modelling of sediment yield. J Hydrol 324(1-4):301-322

Mishra SK, Gajbhiye S, Pandey A (2013) Estimation of design runoff curve numbers for Narmada watersheds (India). J Appl Water Eng Res 1(1):69-79 (ISSN 2324-9676)

Moglen GE (2000) Effect of orientation of spatially distributed curve numbers in runoff calculations. J Am Water Res Assoc 36(6):1391-1400

Ponce VM, Hawkins RH (1996) Runoff curve number: has it reached maturity? J Hydrol Eng 1(1):11-19

Rallison RE (1980) Origin and evolution of the SCS runoff equation. In: Proceedings of ASCE irrigation and drainage division symposium on watershed management, vol 2. ASCE, New York, pp 912-924

SCS (1956, 1964, 1969, 1971, 1972, 1985, 1993). Hydrology, national engineering handbook, supplement A, section 4, chapter 10. Soil Conservation Service, USDA, Washington, DC

Sharpley AN, Williams JR (1990) EPIC—erosion/productivity impact calculator: 1. model documentation. Technical Bulletin No. 1768, US Department of Agriculture, US Government Printing Office, Washington, DC

Young RA, Onstad CA, Bosch DD, Anderson WP (1989) AGNPS: a non-point source pollution model for evaluating agricultural watersheds. J Soil Water Conserv 44(2): 168-173

$\mathrm{Yu}$ BF (1998) Theoretical justification of SCS method for runoff estimation. J Irrig Drain Eng 124(6):306-310 